\title{
The Influence of Morals and Leadership on Job Performance at Infantry Units
}

\author{
W. Norhasniah W. Husin and Ahmad Azan Ridzuan \\ National Defense University of Malaysia \\ Sungai Besi Camp, 57000 Kuala Lumpur, Malaysia \\ hasni_wan02@yahoo.com \\ azan@upnm.edu.my
}

\begin{abstract}
The objective of the study is to investigate the influence of morals and leadership on the job performance at an Infantry Units in Sungai Besi Camp. It involved 326 respondents of different backgrounds and the data were analyzed using several statistical methods including structural equation modeling SmartPLS version 3.0. The results show that both the correlation between Morals and leadership are significant with job performance the $\beta$ values of 0.170 and 0.218 with the corresponding $t$ values of 3.330 and 4.333 respectively.
\end{abstract}

Keywords—morals; leadership; job performance; infantry unit; SmartPLS

\section{INTRODUCTION}

Job performance is one of the most significant factor that affect the performance of an organization because it is directly related to profitability, productivity and the level of impairment of the organization [1]. In fact it should be the core construct of today's work place as suggested by Visveswaran [2]. Besides it is also an indicator for employee job satisfactory and the feeling of task accomplishment.

Existing research has established links between job performance and morals. Weakliem studied on the relationship between morals and workplace performance and found that enhancing morals not only makes work more pleasant but also produces productivity gains. According to Walker [3], evidence shows that integration of faith and work is indeed related to important life and work outcomes, and thus worthy of future study. In another study by Schwepker, and Ingram [4], found that morals judgment is positively related the salesperson performance. Besides, the study also suggests sale people knowingly violating ethical standard should be remove from the organization. In military sphere the creation of ethical climate is important in order to faithfully accomplish any assigned task and there has been an increasing evidence to suggest that a strong ethical climate is essential in preventing unethical acts [5]. This is of paramount important when the decision of a member in an organization or a unit will affect the rest of the members. A study in Taiwanese military units showed that ethical work environment significantly positively influenced overall organization commitment affective commitment, continuance commitment and normative commitment [6].

\author{
Wan Kamal Mujani \\ Department of Arabic Studies \& Islamic Civilization \\ Faculty of Islamic Studies \\ The National University of Malaysia, 43600 Bangi Malaysia \\ inawan@ukm.edu.my
}

Amportant aspect that significantly affects the job performance is the leadership. It is defined as a process whereby an individual influences a group of individuals to achieve a common goal [7][8]. Theoretically, there are three basic ways on a person becomes a leader: The Trait Leadership, whereby a situation where some personality traits may lead somebody naturally into leadership role. The second theory is called the Great Events Theory, whereby a leader emerges out of major event or crisis that brings out extraordinary leadership qualities in an ordinary person. The last theory is known as Process Theory in which the leadership skills are learned and nurtured. This transformational leadership style normally aims to improve the condition of the followers in order efficiently achieve the organizational goals. A study by Toor \& Ofori shows that ethical leadership is more likely to bring about leaders effectiveness, willingness of employees to put more efforts which at the end will increase the employee's job performance [9].

\section{METHODOLOGY}

The study adopted a quantitative approach to investigate the relationship between morals and leadership as independent variables with respect to job performance. Based on this research conceptual framework there are two (2) hypotheses generated as shown in Fig. 1.

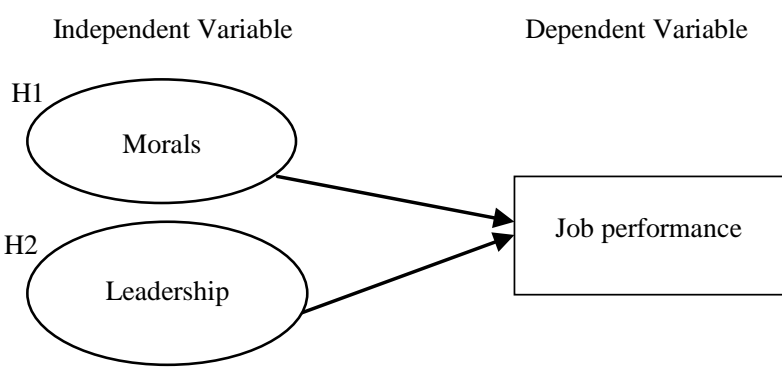

Fig. 1. The relationship between morals, leadership and job performance

The empirical research of this work is based on the following hypotheses:

Hypothesis 1: There is a relationship between elements of morals and job performance.

Hypothesis 2: There is a relationship between elements of leadership and job performance. 
The research included a cross-sectional study and a set of self-structured research questionnaires was distributed at Army Field Headquarters, First Battalion of Royal Malay Regiment and Headquarters of Staff Station Sungai Besi. The total of useable samples obtained was 326 from the studied organization.

The questionnaires consist of three sections. The first section deals with the demographic respondents which include sex, rank, team, age, marital status, duration of service and education background. For the second section, 10 items provided to deal on morals and 19 items on leadership and 16 items for job performance indicators which include knowledge on job description and its scope and problem solving techniques. These questionnaires were based on literature review extracted from Ali [10], Allen and Meyer's [11], Farsi et al. [12], Lee and Choi [13], and Kuvaas [14]. As for the measurement it was based on the scale of 1 to 7 which 1 represents strongly disagree and 7 denotes strongly agree. All the Cronbach Alfa values are above 0.7 which indicates the reliability or the internal consistency of the data is good. The statistical analysis of the data was carried out based on Structural Equation Modeling of Smart PLS version 3.0.

\section{RESULTS}

TABLE I.

CRONBACH ALFA VALUES

\begin{tabular}{|c|c|}
\hline Variable & Cross study Cronbach Alfa values \\
\hline Morals & 0.769 \\
\hline Leadership & 0.881 \\
\hline Job performance & 0.827 \\
\hline
\end{tabular}

TABLE II. DESCRIPTIVE STATISTICAL ANALYSES FOR THE STUDIED VARIABLES

\begin{tabular}{|c|c|c|c|}
\hline \multirow{2}{*}{$\begin{array}{l}\text { Descriptive } \\
\text { Statistics }\end{array}$} & \multicolumn{3}{|c|}{ Variables } \\
\hline & Morals & Leadership & Job Performance \\
\hline \multirow{13}{*}{$\begin{array}{c}\text { Min } \\
\text { Median } \\
\text { Standard deviation } \\
\text { Minimum } \\
\text { Maximum } \\
\text { Range } \\
\text { The interquartile } \\
\text { range } \\
(I Q R) \\
\text { skewness } \\
\text { Kurtosis } \\
\text { percentile } \\
25^{\text {th }} \\
50^{\text {th }} \\
75^{\text {th }} \\
90^{\text {th }}\end{array}$} & 6.20 & 5.74 & 5.89 \\
\hline & 6.40 & 5.95 & 6.00 \\
\hline & 0.813 & 0.886 & 0.909 \\
\hline & 3 & 1 & 1 \\
\hline & 7 & 7 & 7 \\
\hline & 4 & 6 & 6 \\
\hline & 1 & 1 & 1 \\
\hline & -1.792 & -1.844 & -2.565 \\
\hline & 3.840 & 6.455 & 10.105 \\
\hline & & & \\
\hline & $\begin{array}{l}6.00 \\
6.40\end{array}$ & $\begin{array}{l}5.32 \\
5.95\end{array}$ & $\begin{array}{l}5.67 \\
6.00\end{array}$ \\
\hline & 6.80 & 6.26 & 6.44 \\
\hline & 7.00 & 6.68 & 6.75 \\
\hline \multicolumn{4}{|c|}{ Level } \\
\hline $\begin{array}{c}\text { Unsatisfactory (1- } \\
2.33)\end{array}$ & 0 & $3(0.9)$ & $5(1.5)$ \\
\hline $\begin{array}{c}\text { Satisfactory (2.34- } \\
3.67)\end{array}$ & $10(3.1)$ & $6(1.8)$ & $4(1.2)$ \\
\hline $\begin{array}{c}\text { Very satisfactory } \\
(3.68-5.00)\end{array}$ & 316(96) & $317(97.2)$ & 318(97.5) \\
\hline
\end{tabular}

The above results indicate that the respondents think themselves of possessing high morals values. Out of the scale 1 to 7 , none is in the range of $1-2.33$ and $96 \%$ is in the highest range of 3.68 to 5.00 which means that the level of morals is relatively high. As for the leadership, the medium value of 5.95 with standard deviation of 0.886 and the min value of 5.74 which indicates the level of leadership is also relatively high. The results also show that only $10 \%$ of the respondents with the reading of 6.68 and above. Overall only $0.9 \%$ said that their leadership level is unsatisfactory, $1.8 \%$ said it was satisfactory and $97.2 \%$ said they have excellent level of leadership. The min value for job performance 5.89 gives an indication, on overall, the high level performance.

TABLE III. MEAN, STDEV, T-VALUE, P-VALUE (N=326)

\begin{tabular}{|c|c|c|c|c|c|}
\hline & $\begin{array}{c}\text { Original } \\
\text { Sample } \\
(\mathbf{O})\end{array}$ & $\begin{array}{c}\text { Sample } \\
\text { Mean } \\
(\mathbf{M})\end{array}$ & $\begin{array}{c}\text { Standard } \\
\text { Deviation } \\
\text { (STDEV) }\end{array}$ & $\begin{array}{c}\text { T Statistics } \\
(\mid \mathbf{O} / \text { STDEV|) }\end{array}$ & $\begin{array}{c}\mathbf{P} \\
\text { Values }\end{array}$ \\
\hline $\begin{array}{c}\text { Morals-> } \\
\text { Job } \\
\text { Performance }\end{array}$ & 0.170 & 0.173 & 0.051 & 3.330 & 0.001 \\
\hline $\begin{array}{c}\text { Leadership - } \\
>\text { Job } \\
\text { Performance }\end{array}$ & 0.218 & 0.219 & 0.050 & 4.333 & 0.000 \\
\hline
\end{tabular}

TABLE IV. SMARTPLS RESULTS

\begin{tabular}{|c|c|c|c|c|}
\hline Relation & $\boldsymbol{\beta}$ & $\mathbf{t}$ & $\mathbf{R}^{2}$ & Results \\
\hline $\begin{array}{c}\text { Morals-----> Job } \\
\text { performance }\end{array}$ & $0.170^{* * *}$ & 3.330 & & Significant \\
\hline $\begin{array}{c}\text { Leadership -----> } \\
\text { Job performance }\end{array}$ & $0.218^{*}$ & 4.333 & 0.727 & Significant \\
\cline { 3 - 3 }
\end{tabular}

\section{SUMMARY}

The above results indicate that both morals and leadership have significant correlations with job performance.

\section{ACKNOWLEDGMENT}

This research was financially supported by Ministry of Higher Education (Malaysia) and The National University of Malaysia (Grant No. RACE-2015/2017-001).

\section{REFERENCES}

[1] E. A. Jamsari, W. K. Mujani, N. I. Ya'akub et al., The Basis of leadership in Islam, Advances in Natural and Applied Sciences, vol.6(8), 2012, pp. 1399-1404.

[2] C. Visveswaran and D. S. Ones, Perspective on models of job performance, International Journal of Selection and Assessment, vol.8, 2000, pp. 261-226.

[3] A. G. Walker, The Relationship between the integration of faith and work with life and job outcomes, Journal of Business Ethics, vol. 112 (3), 2013, pp.453-461.

[4] Jr. C. H. Schwepker and T. N. Ingram, Improving sales performance through ethics: the relationship between salesperson morals judgment 
and job performance, Journal of Business Ethics, vol. 15 (11), 1996, pp.1151-1160.

[5] P. K. Ahmed S. Machold, The quality of ethics connection: towards virtuous organization, Total Quality Management, vol. 15 (4), 2004, pp. 527-545.

[6] Ying-Cheng Huanh, Tsung-Ying Tsai and Yu-Fen Wu, The effect of ethical work climate on organization commitment in Taiwan military units, Chinese Management Studies, vol. 9(4), 2015, pp. 664-680.

[7] E. A. Jamsari, W. K. Mujani, N. I. Ya'akub et al., The Basis of leadership in Islam, Advances in Natural and Applied Sciences, vol.6(8), 2012, pp. 1399-1404.

[8] G. Northouse, Leadership Theory and Practice, New Delhi: Sage Publication Inc., 2007.

[9] S. Toor and G. Ofori, Ethical leadership: examining the relationships with full range leadership model, employee outcomes, and organizational culture, Journal of Business Ethics, vol. 90, 2009, pp. 533-547.
[10] A. Ali, Scaling an Islamic work ethics, The Journal of Social Psychology, vol. 128(5), 2001, pp. 575-783.

[11] N.J. Allen and J.P. Meyer, The measurement and antecedents of affective, continuance and normative commitment to the organization, Journal of Occupational Psychology, vol. 63(1), 1990, pp. 1-18.

[12] J.Y. Farsi et al., Investigating the relationship between Islamic work ethics and organizational commitment and its components: a case study of Gilan province police employees, Journal UMP Social Sciences and Technology Management, vol.3 (2), 2015, pp. 238-244.

[13] H. Lee and B. Choi, Knowledge management enablers, processes, and organizational performance: an integrative view and empirical examination, Journal of Management Information Systems, vol.20 (1), 2003, pp. 179-228.

[14] B. Kuvaas, The interactive role of performance appraisal reactions and regular feedback, Journal of Managerial Psychology, vol. 26 (2), 2011, pp. 123-137. 